\title{
Geohelminth contamination of public areas and epidemiological risk factors in Curitiba, Brazil
}

Contaminação por geohelmintos em áreas públicas e fatores de risco epidemiológicos em Curitiba, Brasil Lew Kan Sprenger ${ }^{1 *}$; Kerriel Thandile Green ${ }^{1,2}$; Marcelo Beltrão Molento ${ }^{1}$

${ }^{1}$ Laboratory of Parasitic Diseases, Department of Veterinary Medicine, Federal University of Paraná - UFPR, Curitiba, PR, Brazil

${ }^{2}$ Private Veterinary Practitioner, Jamaica West Indies, St. Catherine, Jamaica

Received September 18, 2013

Accepted December 13, 2013

\begin{abstract}
This study aimed to investigate the frequency of geohelminthic contamination of public parks and squares in Curitiba, state of Paraná, Brazil, between August and December 2010. A total of 345 samples were collected from 69 sandboxes in different areas and were tested using the Faust, Lutz and Baermann parasitological techniques. Potential risk factors associated with soil contamination were also analyzed. A total of $36 \%$ of the samples (124/345) were positive for helminths and $65.2 \%$ of the areas $(45 / 69)$ were classified as contaminated in one or more samples. The most commonly identified parasite eggs were Ancylostoma sp. (14.5\%; 50/345); followed by Toxocara sp. (9.6\%; $33 / 345)$ and the Strongyloidea superfamily (excluding hookworms) $(2.3 \% ; 8 / 345)$. The analysis on the epidemiological risk factors indicated that the presence of dogs and feces in the sandboxes increased the chances of contamination of the site. Use of fences had a protective positive impact that reduced soil contamination. Health education programs should be applied within the community to minimize the risk of human contact with dogs' feces. Use of fencing in these areas is highly recommended to prevent or reduce the users' contact with animal excrement.
\end{abstract}

Keywords: Dog, helminths, soil contamination, zoonosis.

\section{Resumo}

Este estudo teve como objetivo investigar a frequência de contaminação por geohelmintos em parques e praças públicas de Curitiba, Paraná, Brasil, entre agosto e dezembro de 2010. Um total de 345 amostras foram coletadas de 69 caixas de areia em diferentes áreas e testadas usando-se as técnicas parasitológicas de Faust, Lutz e Baermann. Potenciais fatores de risco também foram analisados com a contaminaçáo do solo. Um total de 36\% (124/345) das amostras foram positivas, para helmintos e 65,2\% (45/69) das áreas foram classificadas como contaminadas em uma ou mais amostras. Os ovos de helmintos mais identificados foram Ancylostoma sp. 14,5\% (50/345), seguido por Toxocara sp. 9,6\% (33/345) e Strongyloidea superfamília (excluindo ancilostomídeos) 2,3\% (8/345). A análise dos fatores de risco epidemiológico indicou que a presença de cáes e fezes nas caixas de areia aumenta a probabilidade de contaminação do local. $\mathrm{O}$ uso de cercas teve um impacto positivo de proteção e redução da contaminação do solo. Programas de educação em saúde devem ser aplicados dentro da comunidade para minimizar o risco do contato humano com as fezes dos cáes. $\mathrm{O}$ uso de cercas nessas áreas é altamente recomendado, para prevenir ou reduzir o contato dos usuários com excrementos dos animais.

Palavras-chave: Cão, helmintos, contaminação do solo, zoonoses.

\section{Introduction}

The numbers of cats and dogs living closely to humans, thereby aiding in the psychomotor, social and emotional development of their owners/guardians, have been increasing (GODOY; DENZIN, 2007). However, these animals' circulation in public areas as pets or as strays may contaminate the environment

\footnotetext{
${ }^{*}$ Corresponding author: Lew Kan Sprenger

Laboratory of Parasitic Diseases, Department of Veterinary Medicine, Federal

University of Paraná - UFPR, R. dos Funcionários, 1540, CEP 80035-050,

Curitiba, PR, Brazil

e-mail: lew.sprenger@gmail.com
}

with their feces. Moreover, as reported worldwide, dogs may be infected with gastrointestinal parasites, thus passing millions of eggs in their feces daily (BROOKER et al., 2006). Toxocara canis is the most common parasite in pets, with worldwide distribution (BLASZKOWSKA et al., 2013). Other important geohelminths include Ancylostoma spp., Trichuris spp. and Strongyloidea superfamily members (RUBEL; WISNIVESKY, 2010). Hookworms and roundworms are usually the most prevalent parasites in Brazil and their importance changes according to the region studied (GUIMARÃES et al., 2005; KATAGIRI; OLIVEIRA-SEQUEIRA, 
2008; HEUKELBACH et al., 2012). Thus, infected animals can play a major epidemiological role as the source of infection for naïve animals, as well as in transmitting zoonotic diseases to the human population (TORGERSON et al., 2009).

Annually, approximately 300 million people are affected by geohelminths worldwide, of whom $50 \%$ are school-age children (OLIVEIRA et al., 20011. Contamination by endoparasite eggs in sand in public areas and school sandboxes poses a serious health risk for this age group (TORGERSON; MacPHERSON, 2011). Among the major transmittable parasitic diseases are Toxocara sp. and Ancylostoma sp. infections such as ancylostomiasis, mainly due to the risk of visceral larva migrans (VLM), cutaneous larva migrans (CLM) and some protozoan agents (MARTÍNEZMORENO et al., 2007). The problem is intensified in regions that lack basic sanitation and have high densities of human and animal populations (BARRETO et al., 2007). The symptoms resulting from these infections include apathy, colic, diarrhea, malaise and weight loss. VLM is the most dangerous disease in which an ectopic parasite location may lead to human death (NEVES, 2004).

Because of frequent public access to contaminated areas (recreational city parks, sports squares and beaches), the epidemiological importance of these diseases needs to be emphasized. Therefore, studies to determine whether pathological organisms are present in these locations are critical. Through the data thus obtained, the authorities with responsibility for these matters would be able to determine effective health control programs in order to eradicate and/or reduce the prevalence of zoonoses (PEDRASSANI et al., 2008).

The objective of this study was to analyze occurrences of larvae and eggs of helminths and protozoan oocysts/cysts in sand samples collected from public areas in the city of Curitiba, Paraná, Brazil.

\section{Methods}

This study was conducted in the city of Curitiba, Paraná, Brazil, situated at $936 \mathrm{~m}$ above sea level. According to Köppen's climate classification, Curitiba has a subtemperate (Cfb) climate with mild summer month temperatures. Between August and December 2010, five sand samples (50 g each) were collected from separate points in the same area, in 69 out of the 75 sandboxes in public areas of the city ( 66 squares and 3 recreational parks), thus totaling 345 samples. Collections were done on different days between 7:00 and 8:00 AM. Only samples consisting of sand and soil were collected. Areas covered by stones, grass, sediments and those that were within $2 \mathrm{~m}$ of fecal materials were excluded. All the samples were collected with the aid of a garden shovel and were placed in plastic bags. They were then stored in polystyrene foam containers containing ice and were transported to the Parasitic Diseases Laboratory of the Federal University of Paraná (UFPR), on the Agricultural Campus, to be processed and analyzed. At the time of sampling, important epidemiological information was collected: presence of dogs; presence of fencing around the area; presence of dog feces; and type of soil.

In the laboratory, all the samples were homogenized, processed and analyzed by three different methodologies, which included:
Faust et al. (1938) to analyze the presence of cysts and light eggs; Lutz (1919) to view heavy eggs; and Baermann (1917) to recover larvae. In the first two of these methods, four slides of each sample were analyzed under an optical microscope at 10x, with confirmation at 40x. The larvae, oocysts and eggs were identified based on the morphology of each species (BOWMAN, 2010). This method was also enough to differentiate hookworms eggs from Strongyloidea, through observation and measurement of the size, shape and distinctive features of this parasite (CHEESBROUGH, 1998). Although this is not an easy diagnosis to make, a trained parasitologist is able to perceive all these differences.

The data were analyzed by means of the Pearson chi-square test and the chi-square test for linear trend, in order to investigate statistically significant differences relating to the area and location in the city. The risk factor estimates used for the associations were the odds ratio with a confidence interval (with lower and upper limits). All the analyses were developed using the Epi-Info software, version 3.3.2 (CDC/WHO, Atlanta, USA, 2005).

\section{Results}

Regarding parasite distribution in the neighborhoods, just 39.1\% (27/69) of the sandboxes were negative out of all the parasitological tests performed. Of the 345 samples analyzed, 36\% (124/345) were positive in more than one of the tests used. Contamination was observed in $63.6 \%$ squares (42/66) and in $100 \%(3 / 3)$ of the recreational parks, and most of the areas (65.2\%; 45/69) were positive for one or more types of small animal endoparasites. Only $11.1 \%(5 / 45)$ of the positive samples occurred in neighborhoods located in the central region of the city.

Among the species found, the highest positivity rate was in relation to hookworm eggs $(14.5 \%$; 50/345), followed by Toxocara spp. $(9.6 \% ; 33 / 345)$ and the Strongyloidea superfamily (excluding hookworms) $(2.3 \% ; 8 / 345)$. Out of the 124 positive samples, $13.7 \%(17 / 124)$ represented multiple contaminations. In this case, the most frequent association found was between hookworms and Toxocara spp. (2.0\%; 7/345) (Table 1). In some cases, embryonated Toxocara spp. and hookworms eggs were observed, although this was not a common trend.

There was a significant association between soil contamination and the presence of cats and dogs near the collection site $(\mathrm{p}<0.0001)$ (Table 2). It was also observed that the larger the number of animals seen was, the greater the chance of sample positivity would be, with a crude odds ratio of 3.7632 (2.0229 to 7.0005) for between one and four animals and 18.2619 (9.3404 to 35.7048) when it was greater than five animals.

With regard to the presence of fencing around the sandboxes, the crude odds ratio was $0.2306(0.1097$ to 0.4848$)$. In this case, a significant correlation was observed $(\mathrm{p}<0.0001)$ with soil contamination when fences were not present.

A significant association between soil contamination and the quantity of animal feces (cat or dog) near the collection site was observed ( $\mathrm{p}<0.0001)$. The probability of positive samples was greater when the number of risk factors was also greater, with a crude odds ratio of 3.0270 (1.7823 to 5.1412) for the presence 
Table 1. Helminths diagnosed in soil samples from public places in the municipality of Curitiba, state of Paraná, Brazil, 2009.

\begin{tabular}{lccc}
\hline \multicolumn{1}{c}{ Helminths } & Positive samples & Absolute percentage (\%) & Relative percentage (\%) \\
\hline Ancylostoma spp. & 50 & 40.32 & 14.49 \\
Toxocara spp. & 33 & 26.61 & 9.57 \\
Strongyloidea superfamily* & 8 & 6.45 & 2.32 \\
Trichuris spp. & 6 & 4.84 & 1.74 \\
Ancylostoma larvae & 6 & 4.84 & 1.74 \\
Ascaroidea superfamily** & 4 & 3.23 & 1.16 \\
\hline \multicolumn{1}{c}{ Associations found } & Positive samples & Absolute percentage (\%) & Relative percentage (\%) \\
\hline Ancylostoma spp. + Toxocara spp. & 7 & 5.65 & 2.03 \\
Ancylostoma spp. + Strongyloidea superfamily* & 2 & 1.61 & 0.58 \\
Ancylostoma spp. + Trichuris spp. & 1 & 0.81 & 0.29 \\
Ancylostoma spp. + Ascaroidea superfamily** & 1 & 0.81 & 0.29 \\
Toxocara spp. + Strongyloidea superfamily* & 1 & 0.81 & 0.29 \\
Toxocara spp. + Trichuris spp. & 1 & 0.81 & 0.29 \\
Ancylostoma spp. + Toxocara spp. + Ancylostoma larvae & 1 & 0.81 & 0.29 \\
Total & 124 & 100 & 35.08 \\
\hline
\end{tabular}

*Eggs belonging to the Strongyloidea excluding Ancylostoma spp. ${ }^{* *}$ Eggs belonging to the Ascaroidea excluding Ascaris.

Table 2. Analysis of risk factors associated with parasitological contamination of sandboxes in the municipality of Curitiba, state of Parana, Brazil, 2009.

\begin{tabular}{|c|c|c|c|c|}
\hline Risk factor & Positive cases & $\begin{array}{c}\text { Percentage } \\
(\%)\end{array}$ & P value & Odds ratio (with $95 \% \mathrm{CI}$ ) \\
\hline \multicolumn{5}{|l|}{ Dogs } \\
\hline$\geq 5$ & 59 & 17.10 & & $18.26(9.34-35.70)$ \\
\hline 1 to 4 & 33 & 9.57 & $<0.0001$ & $3.76(2.02-7.00)$ \\
\hline 0 & 22 & 6.38 & & 1Ltab.00 \\
\hline \multicolumn{5}{|l|}{ Feces } \\
\hline$\geq 5$ & 43 & 12.46 & & $7.82(4.08-14.99)$ \\
\hline 1 to 4 & 56 & 16.23 & $<0.0001$ & $3.03(1.78-5.14)$ \\
\hline 0 & 30 & 8.70 & & 1.00 \\
\hline \multicolumn{5}{|l|}{ Fences } \\
\hline Yes & 9 & 2.61 & 0.0001 & $0.23(0.11-0.48)$ \\
\hline No & 115 & 33.33 & & 1.00 \\
\hline
\end{tabular}

of one to four piles of excrement and 7.8182 (4.0767 to 14.9936) for five or more.

\section{Discussion}

Soil contamination with helminth parasites presents great danger to public health and continues to be an important problem in developing countries (PAPINI et al., 2012). A high contamination rate was observed in the locations examined in Curitiba. In the state of Rio de Janeiro, Brener et al. (2008) investigated soil contamination in 60 squares in three different cities and found that 30\% (18/60) were contaminated. In a study done in Fernandopólis, São Paulo, 60\% (27/45) of the samples from sand obtained from school sandboxes and public areas were positive (CASSENOTE et al., 2011). In a study done in Guarulhos, São Paulo, 74.5\% (35/47) of the areas analyzed were positive for geohelminths (MARQUES et al., 2012). Similar values were obtained from previous studies conducted in Brazil (SPÓSITO; VIOL, 2012).
The quantity of positive samples detected in at least one of the tests used in this study was similar to the results obtained from other studies. In Canoinhas, Santa Catarina, 39\% (39/100) of the samples showed presence of eggs (PEDRASSANI et al., 2008). In Maceió, Alagoas, 57.5\% (69/120) of the cases showed presence of geohelminths (OLIVEIRA et al., 2011. The problem of contamination of sandboxes is widespread in Brazil, and the percentage depends on the epidemiological characteristics of the area examined.

The influence of the location of the area on the environmental contamination is an ongoing controversy. In Sorocaba, São Paulo, there was no difference in contamination between central or peripheral neighborhoods (COELHO, 2001). In Ribeirão Preto, São Paulo (CAPUANO; ROCHA, 2005), and Paranapanema, São Paulo (SANTARÉM et al., 2012), the contamination occurred mainly in the suburbs. This may be because animals living in urban areas have less access to sandboxes and the socioeconomic status of the residents in central areas allow them to keep their animals under anthelmintic treatments and restrained by a leash (HABLUETZEL et al., 2003). 
In the present study, the main eggs encountered were hookworms and Toxocara spp. Emphasis should be placed on the importance of these results due to the great number of people, especially children, using these areas intensively. These parasites have also been identified contaminating beaches, public parks and school sandboxes in all Brazilian regions (GALLINA et al., 2011).

In a study conducted in Pelotas, Rio Grande de Sul (MOURA et al., 2013), the positive sampling rate for hookworm eggs was $13.5 \%$ (54/400), and it was 8.8\% (35/400) for Toxocara spp.. In Uruguaiana, Rio Grande de Sul (FIGUEIREDO et al., 2012), hookworm eggs were found in $19.2 \%$ (25/130) of the samples and Toxocara spp. in 7.7\% (10/130). Our results were also similar to other studies conducted in Canoinhas (PEDRASSANI et al., 2008); Duque de Caxias (BRENER et al., 2008); Guarulhos (MARQUES et al., 2012) and Lavras (THOMÉ et al., 2009). So far, there have not been any records in Paraná of the presence of any parasites belonging to the superfamilies Ascaroidea and Strongyloidea (Toxocara or Ancylostoma, respectively).

The analysis on the epidemiological risk factors used in our study indicated that there was a positive correlation between the presence of dogs and feces in the area and the possibility of sample contamination. Similar values were also found in studies done in Fernandópolis, where the presence of five or more dogs increased the possibility of contamination ninefold, compared with uninfected areas (CASSENOTE et al., 2011). Presence of contamination sources near to sandboxes should be avoided, because they can transmit pathological agents such as zoonotic parasite eggs and cysts (ZIBAEI et al., 2010).

The presence of fencing was a significant protective factor that prevented soil contamination. In Curitiba, areas with fences had four times less chance of contamination, compared with open areas. Fencing the recreational area is the method most indicated for controlling access by stray animals to sandboxes, and it is an effective method of protection (MARCHIORO et al., 2013). Other simple techniques that can help diminish the number of feces in the environment are public awareness programs within the community, distribution of educational material and putting up warning signs at the locality.

Other animals besides dogs and cats may have had access to the sandboxes examined here, given that only a few of them had protection. Moreover, even when protective measures are present, these are not enough to impede entry by small pets. Some animals that are common among Curitiba's urban wildlife, such as skunks and birds, can be contaminated with members of the superfamilies Ascaroidea and Strongyloidea. The possibility that these animals might defecate in sandboxes is small but nonzero. These animals cannot be exterminated, but control measures should be implemented so that they do not perpetuate parasitic diseases and other types of harm to human and animal health and environmental degradation (QUEIROZ et al., 2008).

We also believe that the data reported both in this study and in the literature are single data points that report moments in time, towards monitoring the presence of infective stages of some important parasites. However, we take the view that a much higher number of eggs and oocysts that were destroyed by biotic external conditions that were not reported could have been present. Therefore, we encourage further studies, which could be conducted such that they would include data on season, climate and more frequent sampling over the course of the year, as risk factors to better describe the importance of determining the epidemiology of some free-living stages of parasites, in order to avoid infection of animals and the population.

\section{Conclusion}

Most of the recreational areas in Curitiba represent an important source of transmission of infective stages of parasites to animals and geohelminthic zoonotic diseases to humans (Ancylostoma sp. and Toxocara sp.). Parasite control measures together with educational programs for public awareness, thus promoting responsible ownership and feces collection, may result in significant reduction of environmental contamination (e.g. in sandboxes). Physical animal restriction measures (e.g. fencing) should also be implemented in order to restrict and reduce the movement of domestic and stray animals in these environments, as shown by in determining the risk factors.

\section{References}

Baermann G. A simple method for finding anchylostomum (nematode) larvae in soil samples. Welteureden Batavia Geneesk Tijschr Ned Ind 1917; 57: 131-137.

Barreto ML, Genser B, Strina A, Teixeira MG, Assis AMO, Rego $\mathrm{RF}$, et al. Effect of city-wide sanitation programme on reduction in rate of childhood diarrhoea in northeast Brazil: assessment by two cohort studies. Lancet 2007; 370(9599): 1622-1628. http://dx.doi.org/10.1016/ S0140-6736(07)61638-9

Blaszkowska J, Wojcik A, Kurnatowski P, Szwabe K. Geohelminth egg contamination of children's play areas in the city of Lodz (Poland). Vet Parasitol 2013; 192(1-3): 228-233. http://dx.doi.org/10.1016/j. vetpar.2012.09.033

Bowman DD. Georgis Parasitologia Veterinária. 9th ed. Elsevier Brasil: São Paulo; 2010.

Brener B, Mattos DPBGD, Millar PR, Arashiro EKN, Duque-Ferreira V, Sudré AP. Estudo da contaminação de praças públicas de três municípios do Estado do Rio de Janeiro, Brasil, por ovos e larvas de helmintos. Rev Patol Trop 2008; 37(3): 247-254.

Brooker S, Clements A, Bundy DAP. Global epidemiology, ecology and control of soil-transmitted helminth infections. Adv Parasitol 2006; 62: 223-265. http://dx.doi.org/10.1016/S0065308X(05)62007-6

Capuano DM, Rocha GM. Environmental contamination by Toxocara sp. eggs in Ribeirão Preto, São Paulo, Brazil. Rev Inst Med Trop S Paulo 2005; 47(4): 223-226. http://dx.doi.org/10.1590/S003646652005000400009

Cassenote AJF, Pinto Neto JM, Lima-Catelani ARA, Ferreira AW. Contaminação do solo por ovos de geo-helmintos com potencial zoonótico na municipalidade de Fernandópolis, Estado de São Paulo, entre 2007 e 2008. Rev Soc Bras Med Trop 2011; 44(3): 371-374. http:// dx.doi.org/10.1590/S0037-86822011005000026

Cheesbrough M. Manual Health Technology. London: ELBS ed., Butterworth-Heinman Ltda., 1998. 
Coelho LMPS, Dini CY, Milman MHSA, Oliveira SM. Toxocara spp. eggs in public squares of Sorocaba, São Paulo State, Brazil. Rev Inst Med Trop S Paulo 2001; 43(4): 189-191. http://dx.doi.org/10.1590/S003646652001000400002

Faust EC, D’Antoni JS, Odom V, Miller MJ, Peres C, Sawitz W, et al. A critical study of clinical laboratory technics for the diagnosis of protozoan cysts and helminth eggs in feces. 1 - Preliminary communication. Am J Trop Med 1938; 18(2): 169-183.

Figueiredo MIDO, Wendt EW, Santos HTD, Moreira CM. Levantamento sazonal de parasitos em caixas de areia nas escolas municipais de educação infantil em Uruguaiana, RS, Brasil. Rev Patol Trop 2012; 41(1): 36-46. http://dx.doi.org/10.5216/rpt.v41i1.17744

Gallina T, Silva MAMP, Castro LLD, Wendt EW, Villela MM, Berne MEA. Presence of eggs of Toxocara spp. and hookworms in a student environment in Rio Grande do Sul, Brazil. Rev Bras Parasitol Vet 2011; 20(2): 176-177. http://dx.doi.org/10.1590/S198429612011000200016

Godoy ACDS, Denzin SS. Atividades assistidas por animais: aspectos revisivos sob um olhar pedagógico. Ensaios Cienc 2007; 5(5): 14-22.

Guimarães AM, Alves EGL, Rezende GF, Rodrigues MC. Ovos de Toxocara sp. e larvas de Ancylostoma sp. em praça pública de Lavras, MG. Rev Saúde Pública 2005; 39(2): 293-295. http://dx.doi.org/10.1590/ S0034-89102005000200022

Habluetzel A, Traldi G, Ruggieri S, Attili AR, Scuppa P, Marchetti $\mathrm{R}$, et al. An estimation of Toxocara canis prevalence in dogs, environmental egg contamination and risk of human infection in the Marche region of Italy. Vet Parasitol 2003; 113(3-4): 243-252. http://dx.doi.org/10.1016/ S0304-4017(03)00082-7

Heukelbach J, Frank R, Ariza L, Lopes ÍS, Silva ADA, Borges AC, et al. High prevalence of intestinal infections and ectoparasites in dogs, Minas Gerais State (southeast Brazil). Parasitol Res 2012; 111(5): 1913-1921. http://dx.doi.org/10.1007/s00436-012-3037-0

Katagiri S, Oliveira-Sequeira TCG. Prevalence of dog intestinal parasites and risk perception of zoonotic infection by dog owners in São Paulo State, Brazil. Zoonoses Public Health 2008; 55(8-10): 406-413. http:// dx.doi.org/10.1111/j.1863-2378.2008.01163.x

Lutz A. O Schistosomum mansoni e a schistosomatose segundo observaçóes, feitas no Brazil. Mem Inst Oswaldo Cruz 1919; 11(1): 121155. http://dx.doi.org/10.1590/S0074-02761919000100006

Marchioro AA, Colli CM, Ferreira EC, Tiyo R, Mattia S, de Souza WF, et al. Identification of public areas with potential toxocariasis transmission risk using Geographical Information Systems. Acta Parasitol 2013; 58(3): 328-333. http://dx.doi.org/10.2478/s11686$013-0142-\mathrm{x}$

Marques JP, Guimarães CR, Boas AV, Carnaúba PU, Moraes JD. Contamination of public parks and squares from Guarulhos (São Paulo State, Brazil) by Toxocara spp. and Ancylostoma spp. Rev Inst Med Trop $S$ Paulo 2012; 54(5): 267-271. http://dx.doi.org/10.1590/S003646652012000500006
Martínez-Moreno FJ, Hernández S, López-Cobos E, Becerra C, Acosta I, Martínez-Moreno A. Estimation of canine intestinal parasites in Córdoba (Spain) and their risk to public health. Vet Parasitol 2007; 143(1): 7-13. http://dx.doi.org/10.1016/j.vetpar.2006.08.004

Moura MQD, Jeske S, Vieira JN, Corrêa TG, Berne MEA, Villela MM. Frequency of geohelminths in public squares in Pelotas, RS, Brazil. Rev Bras Parasitol Vet 2013; 22(1): 175-178. http://dx.doi.org/10.1590/ S1984-29612013000100034

Neves DP. Parasitologia Humana. 11th ed. Atheneu: São Paulo; 2004.

Oliveira ATG, Silva APPS, Farias CS, Alves MS, Silveira LJD, Farias JAC. Contaminação de ambientes arenosos por helmintos em praças públicas da cidade de Maceió-AL. Rev Semente 2011; 6(6): 21-29.

Papini R, Campisi E, Faggi E, Pini G, Mancianti F. Prevalence of Toxocara canis eggs in dog faeces from public places of Florence, Italy. Helminthologia 2012; 49(3): 154-158. http://dx.doi.org/10.2478/ s11687-012-0031-0

Pedrassani D, Viera AM, Thiem EMB. Contaminação por Toxocara spp. e Ancylostoma spp. em áreas de lazer do município de Canoinhas, SC. Arch Vet Sci 2008; 13(2): 110-117.

Queiroz JPAF, Sousa FDN, Lage RA, Izael MA, Santos AG. Criptococoseuma revisão bibliográfica. Acta Vet Bras 2008; 2(2): 32-38.

Rubel D, Wisnivesky C. Dog fouling and helminth contamination in parks and sidewalks of Buenos Aires City, 1991-2006. Medicina 2010; 70(4): 355-363.

Santarém VA, Dias AP, Felix A, Rodenas RS, Silva AV. Contaminaçáo por ovos de Toxocara spp. em praças públicas das regióes central e periurbana de Mirante do Paranapanema, São Paulo, Brasil. Vet Zootec 2012; 17(1): 47-53.

Spósito JD, Viol BM. Avaliação da contaminação ambiental por parasitas potenciais causadores de zoonoses em espaços públicos de lazer em Apucarana, Paraná, Brasil. Rev Saude Pesq 2012; 5(2): 332-337.

Thomé SM, Lafayette EDP, Pessoa Neto GR. Contaminação ambiental por ovos de Toxocara spp. e Ancylostoma spp. em praças públicas da cidade de Duque de Caxias, estado do Rio de Janeiro. Saúde \& Amb Rev 2009; 3(2): 30-32.

Torgerson PR, MacPherson CNL. The socioeconomic burden of parasitic zoonoses: Global trends. Vet Parasitol 2011; 182(1): 79-95. http://dx.doi. org/10.1016/j.vetpar.2011.07.017

Torgerson PR, Rosenheim K, Tanner I, Ziadinov I, Grimm F, Brunner M, et al. Echinococcosis, toxocarosis and toxoplasmosis screening in a rural community in eastern Kazakhstan. Trop Med Int Health 2009; 14(3): 341-348. http://dx.doi.org/10.1111/j.13653156.2009.02229.x

Zibaei M, Abdollahpour F, Birjandi M, Firoozeh F. Soil contamination with Toxocara spp. eggs in the public parks from three areas of Khorram Abad, Iran. Nepal Med Coll J 2010; 12(2): 63-65. 